University of Nebraska - Lincoln

DigitalCommons@University of Nebraska - Lincoln

Educational Psychology Papers and

Publications

Educational Psychology, Department of

2009

Grade and Gender Differences in Gifted Students' Self-Concepts

Kathleen Moritz Rudasill

University of Nebraska-Lincoln, kmrudasill@vcu.edu

Marla Read Capper

University of Virginia

Regan Clark Foust

University of Virginia

Carolyn M. Callahan

University of Virginia, cmc@virginia.edu

Susan B. Albaugh

University of Virginia

Follow this and additional works at: https://digitalcommons.unl.edu/edpsychpapers

Part of the Educational Psychology Commons

Rudasill, Kathleen Moritz; Capper, Marla Read; Foust, Regan Clark; Callahan, Carolyn M.; and Albaugh, Susan B., "Grade and Gender Differences in Gifted Students' Self-Concepts" (2009). Educational Psychology Papers and Publications. 125.

https://digitalcommons.unl.edu/edpsychpapers/125

This Article is brought to you for free and open access by the Educational Psychology, Department of at DigitalCommons@University of Nebraska - Lincoln. It has been accepted for inclusion in Educational Psychology Papers and Publications by an authorized administrator of DigitalCommons@University of Nebraska - Lincoln. 


\title{
Grade and Gender Differences in Gifted Students' Self-Concepts
}

\author{
Kathleen Moritz Rudasill \\ University of Louisville
}

\author{
Marla Read Capper, Regan Clark Foust, \\ Carolyn M. Callahan, and Susan B. Albaugh \\ University of Virginia
}

\begin{abstract}
Gifted adolescents are poised to make important decisions that will determine the trajectory of their futures. A positive self-concept may lead to higher educational and career aspirations, whereas a poorer self-concept may negatively influence choices and outcomes. Research points to self-concept differences among gifted students of different ages (Chan, 2001) and genders (Hoge \& McShreffrey, 1991; Li, 1988), with declining self-concept among females over time. The purpose of this study was to examine the extent to which self-concept differed among gifted students across grade and gender. Two hundred and sixty older adolescents (grades 8 to $11, n=159$ girls) completed the Self-Perception Profile for Adolescents (Harter, 1988) and 300 younger adolescents (grades 5 to $7, n=$ 171 girls) completed the Self-Perception Profile for Children (Harter, 1985). Results indicate that gifted students' scores in several self- concept domains were lower for older adolescents and girls, but remained relatively high across grade and gender for scholastic self-concept.
\end{abstract}

\section{Introduction}

Self-beliefs provide the lens through which students assess abilities, discover and pursue interests, determine educational paths, and plan careers (VanTassel-Baska, Olszewski-Kubilius, \& Kulieke, 1994). Be-

\footnotetext{
Kathleen Moritz Rudasill is Assistant Professor of Educational Psychology at the University of Louisville. Maria Read Capper is earning her doctorate in educational psychology with emphasis in education and psychology of the gifted at the University of Virginia. Regan Clark Foust earned her doctorate in educational psychology with emphasis on education and psychology of the gifted from the University of Virginia. Carolyn Callahan is Commonwealth Professor of Education in the Curry School of Education at the University of Virginia. Susan B. Albaugh is a doctoral student in educational psychology with a focus on learning and development.
} 
cause gifted adolescents are poised to make important decisions that will determine the trajectory of their futures, a positive self-concept may lead to high educational and career aspirations; on the other hand, a poor self-concept may have a negative influence on long-term choices and outcomes. The existing literature indicates that there are differences in self-concept among gifted students of different ages (Chan, 2001) and genders (Hoge \& McSheffrey, 1991; Li, 1988). In particular, the literature has documented declining self-concept among females as they age. However, much of the data was collected prior to the current focus on ensuring a climate of support for young women and the data on gifted females are not as extensive. Consequently, the purpose of this study is to examine the extent to which self-concept differs among gifted students across grade and gender.

\section{Self-Concept}

Self-concept is generally defined as how one perceives oneself (Pajares \& Schunk, 2001) and focuses on "descriptive and evaluative dimensions" (Strein, 1993; p. 273) of self-perception, stressing "selfperceptions of behavior rather than feelings" (Strein, 1993; p. 273). Self-concept is one of several "self" terms used throughout the literature (Hansford \& Hattie, 1982) and is often used interchangeably with self-esteem and self-efficacy (Marsh \& Craven, 2006). Self-concept refers to views of oneself in specific domains (e.g., academics, physical ability), whereas self-esteem is the global element of self-concept (also referred to as global self-worth; Marsh \& Craven, 2006; Pajares \& Schunk, 2001). Self-efficacy also is evaluative in nature, but it is a judgment of confidence in personal abilities (Bandura, 1997).

The construct of self-concept is built upon internal and external comparisons (Marsh, 1986). On the one hand, self-concept emerges as a result of internal comparisons among different aspects within an individual. Marsh (1986) suggested, for example, that students' comparisons between their perceptions of their verbal abilities and math abilities contribute to their academic self-concepts in each of the two domains. On the other hand, students' academic self-concepts also are formed through perceptions they have of their own abilities compared to perceptions they have of other students' abilities within a given context (i.e., classroom or school). Therefore, it is possible to 
have simultaneous positive and negative views of the self, depending on context (Harter, 1985, 1988; Hoge \& McSheffrey, 1991; Marsh, 1986; Plucker \& Stocking, 2001). A special case of the external comparison process is the big-fish-little-pond effect (BFLPE; Marsh, 1987; Marsh \& Parker, 1984). For example, a highly able student in a classroom with average-ability students would be likely to perceive herself as highly able (BFLPE), but if this same student is in a classroom with other high-ability students, she may develop a lower academic self-concept.

Self-concept has been described in theory and tested in research using four different models: nomothetic, hierarchical, taxonomic, and compensatory (Byrne, 1984; Strein, 1993). The nomothetic model, developed by Soares and Soares (1983), espouses the idea of a "general" self-concept that guides behavior, rather than multiple dimensions of self-concept that apply in different contexts (Strein, 1993). Conversely, the hierarchical model, which is largely based on the work of Shavelson and colleagues (Shavelson \& Bolus, 1982; Shavelson, Hubner, \& Stanton, 1976), represents self-concept as multidimensional. In this model, domain-specific self-concepts (e.g., academic and physical self-concept) fall under a broader, general self-concept. General self-concept, defined as a person's overall perception of oneself, is believed to be more stable than domain-specific self-concepts, which are more context dependent (Shavelson et al., 1976).

Closely related to the hierarchical model is the taxonomic model of self-concept. According to this model, self-concept is multidimensional, but the dimensions are conceptualized as independent of one another (Soares \& Soares, 1983; Strein, 1993). The final approach to self-concept is the compensatory model. Like the hierarchical and taxonomic models, the compensatory model is multidimensional and supports the notion of a general self-concept (Byrne, 1984; Strein, 1993). Unlike the other models, the compensatory model suggests the components are inversely, rather than proportionally or independently, related. That is, a person may have a low self-concept in one domain, yet compensate for it with a high self-concept in another. Of these four self-concept models, the hierarchical model has received the most empirical support (Byrne \& Shavelson, 1986; Marsh, 1990; Marsh \& Craven, 2006; Marsh, Craven, \& Debus, 1991) and is the model upon which our study is based. 


\section{Self-Concept and Achievement}

Researchers have found that for the general population, self-concept and achievement are reciprocal and interactive constructs, resulting in the contention that positive self-concept promotes achievement and achievement promotes positive self-concept (Hamachek, 1995; Pajares \& Schunk, 2001; Strein, 1993). Further, the link between selfconcept and achievement is stronger when domain-specific self-concept is matched with its corresponding area of achievement (Pajares \& Schunk, 2001; Strein, 1993). Self-concept also indirectly influences achievement through its power to predict the value and interest a student has in a subject, course selection, career choice, and, ultimately, adult productivity (Muldoon \& Reilly, 2003; Osipow, 1983; Tenenbaum \& Leaper, 2003).

Research suggests that there is a link between academic achievement and self-concept among gifted students as well. In a recent study of elementary-school-aged gifted students, Olszewski-Kubilius and Turner (2002) found that gifted students' perceptions of their academic abilities also had a strong positive relationship to their performance on related tests. Furthermore, Cornell, Delcourt, Goldberg, and Bland (1995) examined the relationship between achievement and self-concept among second- and third-grade gifted students and found that scholastic self-concept significantly correlated with reading, math, science, and social studies achievement for White students.

\section{Self-Concept and Age and Gender Differences}

Individuals typically experience declines in self-concept during middle to late childhood (i.e., ages 8-11) and again in early adolescence (i.e., ages 11-13), with increases in self-concept during later adolescence (Harter, 2006). These changes have been attributed to individuals' increasing ability to realistically assess abilities in comparison to others and to the emotional, cognitive, and physical changes that occur throughout this period. A longitudinal study of gender differences in self-concept among adolescents in grades 7 to 12 conducted by De Fraine, Van Damme, and Onghena (2007) revealed that all students' self-concept scores declined across time, with girls' scores declining more rapidly than boys'. Indeed, 
in her review of research on the self, Harter (2006) stated that there is abundant evidence supporting gender differences in self-concept. Specifically, research shows that females report lower self-concept than males beginning in middle to late childhood, with differences peaking in middle to late adolescence (Harter, 2006; Kling, Hyde, Showers, \& Buswell, 1999).

Gifted Population. Extant literature suggests that gifted students' self-concept scores vary according to age and gender as well. Chan (2001) examined the psychometric properties of the Self-Perception Profile for Adolescents (SPPA; Harter, 1988) with gifted Chinese adolescents (ages 12 to 18) and found differences in self-concept across age. Specifically, global self-worth was predicted only by perceptions of physical appearance and behavior for younger adolescents, but, for older adolescents, it also was predicted by perceptions of academic and social competence. Similarly, Hoge and McSheffrey (1991) examined predictors of global self-worth for gifted students in grades 5 to 8 and found gender differences. The best predictors of global self-worth for all students were social acceptance, physical appearance, and scholastic competence scores. However, scholastic competence contributed more to girls' global self-worth scores than boys'. Li (1988) also found gender differences in self-concept among gifted students; gifted females in grades 4 through 6 perceived their academic abilities more positively than gifted males of the same age.

In another study comparing groups of gifted individuals, VanTassel-Baska et al. (1994) examined self-concept with seventh- and eighth-grade gifted students. They found differences across socioeconomic status levels, gender, and ethnicity, with economically advantaged students showing higher levels of perceived scholastic competence than disadvantaged students, boys showing higher levels of perceived social acceptance than girls, and African American students showing higher perceived social competence than White students.

A review of the literature also suggests that there is a decline in the self-concepts of gifted girls as they age. For example, in a study of 563 gifted students, Colangelo and Assouline (1995) found that high school girls showed the most significant drop in self-concept scores of all of the gifted students. Kline and Short's (1991) work revealed a similar decline in self-confidence and self-perceived abilities: 
Self-perceived abilities and confidence ... clearly declined progressively from elementary and primary grades through junior high school, and further declined through senior high school. By high school, the females feel significantly less willing to reveal themselves to those around them, hiding their intelligence, sensitivity, and feelings, and trying to act tougher than they are. They do not value, or believe others value, their abilities and feelings as much as they did when they were younger. (p. 120)

Reis $(1987,1998,2002)$ suggested that declines in gifted girls' selfconcept, self-confidence, and efficacy beliefs may stem from external forces (e.g., gender stereotypes and associated barriers erected by parents, schools, and peers) and internal forces (e.g., competing choices and subsequent emotional distress). This theory is echoed by Bell (1989) and Silverman (1995).

Taken together, this research indicates that the gifted population is not a homogenous group. Indeed, from their examination of selfconcept with gifted adolescents using the Self-Description Questionnaire III (SDQ III; Marsh, 1992) and the SPPA, Dixon, Cross, and Adams (2001) concluded that studying gifted students as a single group is misleading; although the students are similar in some respects, they differ significantly in others. For example, in their study, Dixon et al. categorized gifted students in a residential setting into six different clusters of student profiles, with each cluster having unique characteristics. Collectively, existing research suggests complexity and variability among gifted students' self-concept scores. Given the link between self-concept and student outcomes and the variability across groups of gifted students in self-concept as suggested in prior literature, the further documentation of differences can lead to understandings of and potential interventions in the development of self-concept scores among gifted students. Hence, the purpose of this cross-sectional developmental study is to examine differences in self-concept in multiple domains among a population of gifted students across two distinguishing factorsgrade and gender. More specifically, the study posed the following research questions:

1. To what extent do gifted adolescents' self-concept scores differ by grade across self-concept domains? 
2. To what extent do gifted adolescent male and female self-concept scores differ across self-concept domains?

3. To what extent do gifted adolescents' grade and gender interact to contribute to their scores across self-concept domains?

\section{Method}

\section{Participants}

The sample consisted of participants in a 2-week residential summer enrichment program for gifted students in grades 5 to 11. Candidates for the program completed applications including teacher recommendations, standardized achievement or IQ scores, and four short-answer responses, all evaluated according to a rubric scored by raters trained to ensure interrater reliability. In 2004, applications were received from 1,519 students for 935 slots (acceptance rate: $61 \%)$.

To recruit participants, an invitation letter to participate in the study, a consent form, and a parent questionnaire (which was part of a larger study) were sent to parents of all students admitted to the program $(n=935)$. In an effort to solicit additional participation, follow-up letters were mailed and parents were approached at registration. These efforts yielded 669 parent consent forms and questionnaires, which were assigned code numbers upon receipt. Code numbers were used to ensure confidentiality while allowing for identification of each student's grade and gender and correspondence of parent and student data.

Of the 935 program participants, 560 chose to participate in the study. Students with missing data were deleted listwise. Thus, the final sample of study participants consisted of 505 adolescents (197 boys and 308 girls).

In terms of gender and grade, study participants were very similar to students who chose not to participate in the study, except that girls were somewhat overrepresented in the study participant group (59\% of study participants were girls) when compared to the nonstudy participant group ( $51 \%$ of nonstudy participants were girls). 
Fifty-one percent of all students chose to identify an ethnic group to which they belonged. The percentage of students reporting their ethnicity was similar for the study participants (48\%) and nonstudy participants $(51 \%)$. Among students who reported their ethnicity, the majority were Caucasian (70\% of study participants and $72 \%$ of non-study participants). Regarding scores for academic achievement and/or cognitive ability, program participants were permitted to submit a variety of types of test scores for admission to the program. Students in the study and nonstudy groups did not differ on either the rates at which they submitted different types of test scores or their mean percentile scores for the different tests. In general, all program participants' test scores reflected high ability, with nationally normed mean percentile scores between 87 and 95. Table 1 shows the number and percentage of students by gender, grade, and ethnicity and displays mean percentile scores for the types of tests most commonly submitted for study participants and nonstudy participants.

\section{Design and Procedure}

Early in each camp session, typically the second or third evening, those students with parental consent to participate in the study were asked to complete the Self-Perception Profile for Children (SPPC; Harter, 1985; for rising 5th through 7th graders) or the SPPA (Harter, 1988; for rising 8th through 11th graders). Instruments were administered in the dormitory areas by camp counselors. Participants were instructed to refer to the general population of students at their home schools as the comparison group when evaluating themselves on the SPPC or SPPA.

The following steps were taken in order to ensure confidentiality. First, students were placed at least 4 feet away from each other while responding to items. Second, the only document on which participants placed their names was a consent form that was immediately separated from the remaining documents upon receipt by researchers. Finally, once finished, each participant placed all measures inside an envelope, sealed the envelope, and then returned it to the counselor. 
Table 1. Characteristics of Study and Nonstudy Participants

\begin{tabular}{|c|c|c|c|c|}
\hline & \multicolumn{2}{|c|}{ Study Participants } & \multicolumn{2}{|c|}{ Nonstudy Participants } \\
\hline Gender & $n=579$ & & $n=339$ & \\
\hline Girls & 340 & $59 \%$ & 174 & $51 \%$ \\
\hline Boys & 239 & $41 \%$ & 165 & $49 \%$ \\
\hline Grade & $n=579$ & & $n=339$ & \\
\hline 5th & 60 & $10 \%$ & 37 & $11 \%$ \\
\hline 6th & 121 & $21 \%$ & 67 & $20 \%$ \\
\hline 7 th & 126 & $22 \%$ & 57 & $17 \%$ \\
\hline 8th & 115 & $20 \%$ & 76 & $22 \%$ \\
\hline 9th & 70 & $12 \%$ & 49 & $15 \%$ \\
\hline 10th & 51 & $9 \%$ & 28 & $8 \%$ \\
\hline 11th & 36 & $6 \%$ & 25 & $7 \%$ \\
\hline Ethnicity & $n=300$ & & $n=148$ & \\
\hline $\begin{array}{l}\text { African American/ } \\
\text { Black }\end{array}$ & 35 & $13 \%$ & 12 & $8 \%$ \\
\hline Asian & 31 & $10 \%$ & 17 & $11 \%$ \\
\hline Caucasian & 211 & $70 \%$ & 107 & $72 \%$ \\
\hline Hispanic & 9 & $3 \%$ & 2 & $1 \%$ \\
\hline Indian & 4 & $1 \%$ & 1 & $<1 \%$ \\
\hline Mixed & 10 & $3 \%$ & 9 & $6 \%$ \\
\hline \multirow[t]{2}{*}{ Test Scores } & $n=578$ & & $n=339$ & \\
\hline & $n$ & $\begin{array}{l}\text { Mean } \\
\text { Percentile }\end{array}$ & $n$ & $\begin{array}{l}\text { Mean } \\
\text { Percentile }\end{array}$ \\
\hline $\begin{array}{l}\text { Reading } \\
\text { Vocabulary }\end{array}$ & 520 & 88 & 304 & 87 \\
\hline $\begin{array}{l}\text { Reading } \\
\text { Comprehension }\end{array}$ & 529 & 91 & 312 & 91 \\
\hline $\begin{array}{l}\text { Math Problem } \\
\text { Solving }\end{array}$ & 502 & 93 & 294 & 94 \\
\hline Math Procedures & 444 & 87 & 247 & 89 \\
\hline
\end{tabular}

\section{Instruments}

SPPC. The SPPC (Harter, 1985) is designed to measure feelings of competence in five specific domains (scholastic competence, social acceptance, athletic competence, physical appearance, and behavioral 
conduct), as well as overall self-worth (global self-worth) in third- to eighth-grade students. Each subscale contains 6 items. According to Harter (1985), inclusion of global self-worth as an independent aspect of self-concept provides "a richer and more differentiated picture than those instruments providing only a single self-concept score" (p. 5). Hence, specific questions on the Harter Self-Perception Profiles relating to global self-worth are designed to encourage students to evaluate themselves in a holistic fashion. Additionally, unlike other general measures of self-concept, global self-worth is an independent score rather than a sum of responses to items across several more specific domains.

Analyses conducted by Harter suggest that scores obtained from the SPPC are reliable and valid measures of self-perception among the general population. Using four samples of children from the general population, Harter (1985) assessed the internal reliability of the SPPC. The resulting average Cronbach's alpha values were acceptable (.71 to .86$)$. For the current sample, internal reliability values were as follows: scholastic competence $\alpha=.75$, social acceptance $\alpha=.81$, athletic competence $\alpha=.87$, physical appearance $\alpha=.85$, behavioral conduct $\alpha=.85$, and global self-worth $\alpha=.77$.

In terms of structural validity, the factor pattern that emerged from scores of these four samples showed clear factor loadings (average loadings ranged from .43 to .80) onto the five subscales of the SPPC (scholastic competence, social acceptance, athletic competence, physical appearance, and behavioral conduct). The cross-loadings were minimal, and none were greater than .18 (Harter, 1985).

SPPA. "The Self-Perception Profile for Adolescents is an upward extension of the Self-Perception Profile for Children" (Harter, 1988, p. 2 ) for students in grades 8 to 11. Like the SPPC, the adolescent profile attempts to gauge domain-specific self-concepts in addition to an adolescent's overall sense of happiness with self. In addition to the subscales on the SPPC, the SPPA also includes three other subscales, romantic appeal, job competence, and close friendship, to measure constructs that become prominent in adolescence (Harter, 1988). Each subscale contains five items. Harter (1988) structured the language of the items for the subscales common to the SPPC and SPPA so that the scales could be used to compare self-concept scores across different 
age groups. For the purposes of this study, only those scales common to the SPPC and SPPA were used.

Analyses conducted by Harter suggest that scores obtained from the SPPA are reliable and valid for measuring self-perception among the general population. Using four samples of adolescents from the general population, Harter (1988) assessed the internal reliability of the SPPA. The resulting average Cronbach's alpha values were acceptable (.74 to .93$)$. With the current sample, the internal reliability values were as follows: scholastic competence $a=.68$, social acceptance $\alpha=.86$, athletic competence $\alpha=.93$, physical appearance $\alpha=.90$, behavioral conduct $\alpha=.77$, and global self-worth, $\alpha=.84$.

In terms of structural validity, the resulting factor pattern from Harter's (1988) four samples showed clear factor loadings (averages across samples ranged from .47 to .84 ) onto the subscales (scholastic competence, social acceptance, athletic competence, physical appearance, and behavioral conduct; Harter, 1988). As with the SPPC, the cross loadings were minimal, and none were greater than .30 .

Manuals for the SPPC and SPPA (Harter, 1985, 1988) contain warnings that these instruments may not be appropriate for special child and adolescent populations. For example, use of the SPPC with children with learning disabilities and those categorized as intellectually disabled has produced very different factor structures than those emerging from analyses of data on the general population. Therefore, Harter (1988) suggested that alternative scales be developed for special populations and cautioned that when applying these profiles to special populations examiners should instruct students to compare themselves to peers in the general population rather than to others within their special population (Harter, 1985). Results from a recent examination of the factor structures of the Harter Self-Perception Profiles for use with gifted students supported the application of the same six (SPPC) and nine (SPPA) subscales used in the original instruments (see Rudasill \& Callahan, 2008).

\section{Data Analysis}

Multivariate analyses of variance (MANOVAs) were conducted to assess differences in self-concept scores across grade and gen- 
der. First, all students' self-concept scores were compared across grade and gender. Mean scores for each subscale were entered as dependent variables, with grade and gender entered as fixed factors. Due to the specific nature of the research questions regarding self-concept differences between males and females, another set of MANOVAs was conducted to examine self-concept score differences within grades across genders. Each analysis was followed by posthoc univariate $F$ tests of differences. For differences between grades, follow-up pair-wise comparisons among grades were evaluated using Tukey tests. Effect sizes are reported using partial etasquared values. These values may be interpreted as approximating variance explained.

\section{Results}

Means and standard deviations for the subscales of the SPPC and the SPPA for grade by gender appear in Table 2. For the SPPC, scores ranged from 2.63 (athletic competence, seventh grade) to 3.47 (global self-worth, fifth grade) out of a possible range of 1 to 4 . For the SPPA, scores ranged from 2.28 (athletic competence, 10th grade) to 3.52 (behavioral conduct, 11th grade) out of a possible range of 1 to 4 . When compared to means of heterogeneous samples of same-aged students, the mean scores for boys and girls in this sample were higher in almost every self-concept domain. The mean scores for boys in the current sample were higher than the sample means for heterogeneous students in scholastic competence, social acceptance, behavioral conduct, and global self-worth (Harter, 1985, 1988). The mean of boys' scores in the current sample were approximately equal to the means for boys in heterogeneous samples for physical appearance, and the heterogeneous samples of boys had higher mean scores in athletic competence (Harter, 1985, 1988). Differences in girls' mean scores for the current sample and in the heterogeneous samples were the same as those for boys with one exception: the mean score for girls in the current sample was approximately equal to the mean scores among the heterogeneous samples of girls for athletic competence (Harter, 1985, 1988). 
Table 2. Mean Scores on Harter Self-Perception Profile Subscales as a Function of Grade and Gender

\begin{tabular}{|c|c|c|c|c|c|c|c|c|c|c|c|c|c|c|}
\hline \multirow{3}{*}{$\begin{array}{l}\text { Boys } \\
\text { Subscale }\end{array}$} & \multicolumn{14}{|c|}{ Grade } \\
\hline & \multicolumn{2}{|c|}{5 th } & \multicolumn{2}{|c|}{ 6th } & \multicolumn{2}{|c|}{ 7th } & \multicolumn{2}{|c|}{8 th } & \multicolumn{2}{|l|}{ 9th } & \multicolumn{2}{|l|}{ 10th } & \multicolumn{2}{|c|}{ 11th } \\
\hline & M & SD & M & SD & M & SD & M & SD & M & SD & M & SD & M & SD \\
\hline $\begin{array}{l}\text { Scholastic } \\
\text { Competence }\end{array}$ & 3.38 & .47 & 3.41 & .47 & 3.41 & .38 & 3.42 & .54 & 3.38 & .45 & 3.45 & .41 & 3.51 & .37 \\
\hline $\begin{array}{l}\text { Social } \\
\text { Acceptance }\end{array}$ & 3.18 & .68 & 3.02 & .55 & 2.96 & .74 & 3.32 & .49 & 3.11 & .77 & 3.15 & .60 & 3.07 & .59 \\
\hline $\begin{array}{l}\text { Athletic } \\
\text { Competence }\end{array}$ & 3.17 & .64 & 2.89 & .64 & 2.83 & .82 & 2.93 & .75 & 2.84 & .98 & 2.63 & .89 & 2.73 & 1.06 \\
\hline $\begin{array}{l}\text { Physical } \\
\text { Appearance }\end{array}$ & 3.25 & .70 & 2.99 & .57 & 2.86 & .71 & 2.77 & .69 & 2.68 & .74 & 2.83 & .64 & 3.20 & .67 \\
\hline $\begin{array}{l}\text { Behavioral } \\
\text { Conduct }\end{array}$ & 3.20 & .70 & 3.19 & .64 & 3.12 & .55 & 3.04 & .52 & 2.96 & .62 & 3.15 & .59 & 3.40 & .57 \\
\hline $\begin{array}{l}\text { Global Self- } \\
\text { Worth }\end{array}$ & 3.48 & .45 & 3.42 & .45 & 3.40 & .54 & 3.36 & .50 & 3.14 & .89 & 3.30 & .52 & 3.49 & .52 \\
\hline Girls & $5 t$ & & $6 \mathrm{tl}$ & & $7 \mathrm{th}$ & & 8th & & 9th & & 10th & & $11 t$ & \\
\hline Subscale & M & SD & M & SD & $\mathrm{M}$ & SD & $\mathrm{M}$ & SD & M & $\mathrm{SD}$ & M & $\mathrm{SD}$ & M & SD \\
\hline $\begin{array}{l}\text { Scholastic } \\
\text { Competence }\end{array}$ & 3.37 & .58 & 3.51 & .44 & 3.26 & .51 & 3.49 & .48 & 3.47 & .49 & 3.45 & .54 & 3.44 & .55 \\
\hline $\begin{array}{l}\text { Social } \\
\text { Acceptance }\end{array}$ & 3.17 & .68 & 3.19 & .62 & 2.94 & .68 & 3.25 & .65 & 3.28 & .67 & 2.92 & .70 & 3.37 & .51 \\
\hline $\begin{array}{l}\text { Athletic } \\
\text { Competence }\end{array}$ & $2.91_{a}$ & .76 & $2.82_{b}$ & .69 & 2.50 & .79 & $2.59_{c}$ & .88 & 2.53 & .85 & $2.04_{\mathrm{abc}}$ & ${ }_{c} .86$ & 2.57 & .98 \\
\hline $\begin{array}{l}\text { Physical } \\
\text { Appearance }\end{array}$ & $3.03_{a}$ & .89 & $2.89 \mathrm{~b}$ & .74 & 2.78 & .74 & 2.67 & .77 & $2.34_{\mathrm{ab}}$ & .74 & 2.52 & .73 & 2.62 & .76 \\
\hline $\begin{array}{l}\text { Behavioral } \\
\text { Conduct }\end{array}$ & 3.49 & .50 & 3.55 & .43 & 3.43 & .51 & 3.30 & .61 & 3.26 & .60 & 3.23 & .59 & 3.60 & .42 \\
\hline $\begin{array}{l}\text { Global Self- } \\
\text { Worth }\end{array}$ & 3.47 & .59 & $3.44_{\mathrm{a}}$ & b. .53 & 3.30 & .54 & 3.32 & .59 & $3.07_{a}$ & .57 & $3.00_{b}$ & .70 & 3.16 & .70 \\
\hline
\end{tabular}

Means in a row sharing subscripts are significantly different at $p<.0024$

\section{Differences Between All Students in Grades 5 to 11}

Self-concept scores for students in our sample in grades 5 to 11 were compared on the Harter subscales that are common to both the SPPC and the SPPA. The common subscales are scholastic competence, social acceptance, athletic competence, physical appearance, 
Table 3. Correlation Coefficients for Relations Among Six Subscales on the Harter Self-Perception Profiles

\begin{tabular}{lllllll}
\hline Subscale & SC & SA & AC & PA & BC & GSW \\
\hline SC & 1.0 & & & & & \\
SA & $.22^{* *}$ & 1.0 & & & & \\
AC & $.13^{* *}$ & $.37^{* *}$ & 1.0 & & & \\
PA & $.22^{* *}$ & $.34^{* *}$ & $.30^{* *}$ & 1.0 & & \\
BC & $.33^{* *}$ & $.15^{* *}$ & .00 & $.33^{* *}$ & 1.0 & \\
GSW & $.36^{* *}$ & $.46^{* *}$ & $.29^{* *}$ & $.62^{* *}$ & $.46^{* *}$ & 1.0 \\
\hline
\end{tabular}

$\mathrm{SC}=$ Scholastic Competence, $\mathrm{SA}=$ Social Acceptance, $\mathrm{AC}=$ Athletic Competence, PA $=$ Physical Appearance, $\mathrm{BC}=$ Behavioral Conduct, GSW $=$ Global Self-worth . ${ }^{* *} p<.01$.

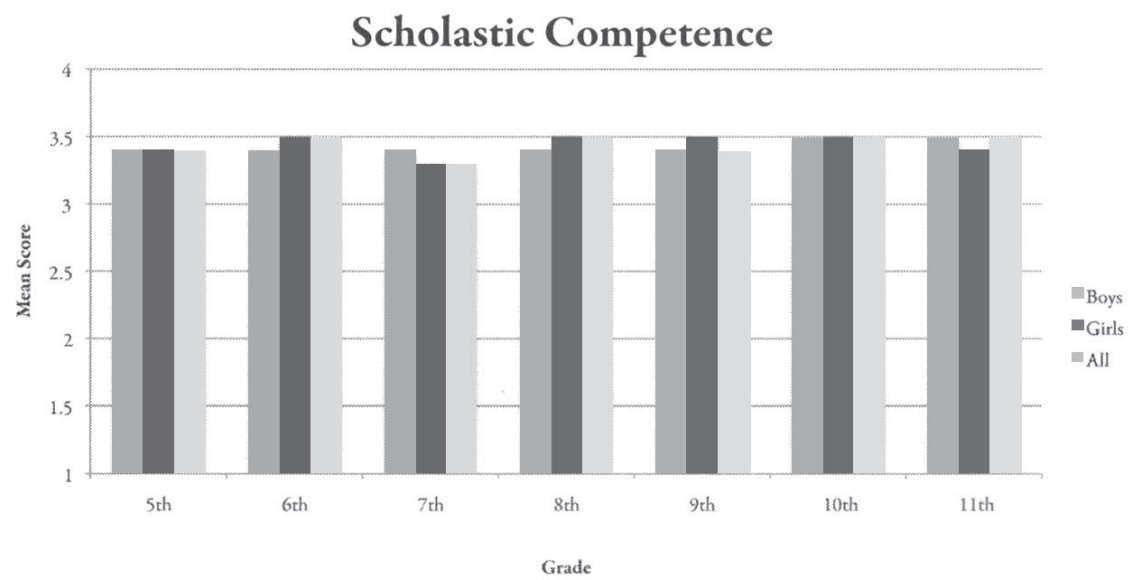

Figure 1. Mean scholastic competence scores for boys, girls, and all students in each grade.

behavioral conduct, and global self-worth. There were statistically significant overall grade differences for self-concept scores in all domains except scholastic competence. Table 2 displays the means and standard deviations of scores for each self-concept subscale across grades by gender. Figures 1 through 6 include the means for each subscale for all students and then separately by gender. A matrix of correlation coefficients for the scores on the common subscales of the SPPC and SPPA is shown in Table 3. 


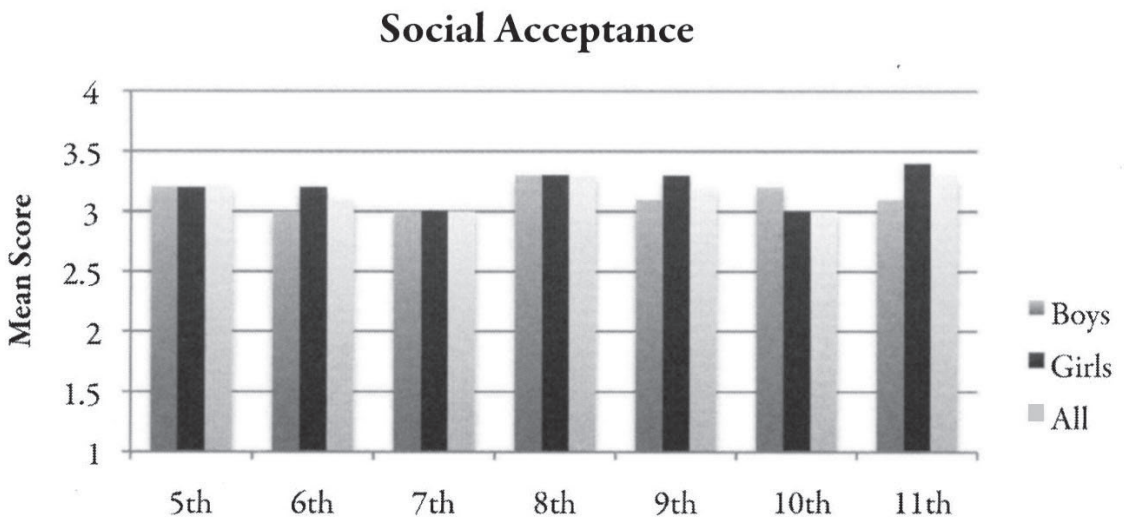

\section{Grade}

Figure 2. Mean social acceptance scores for boys, girls, and all students in each grade.

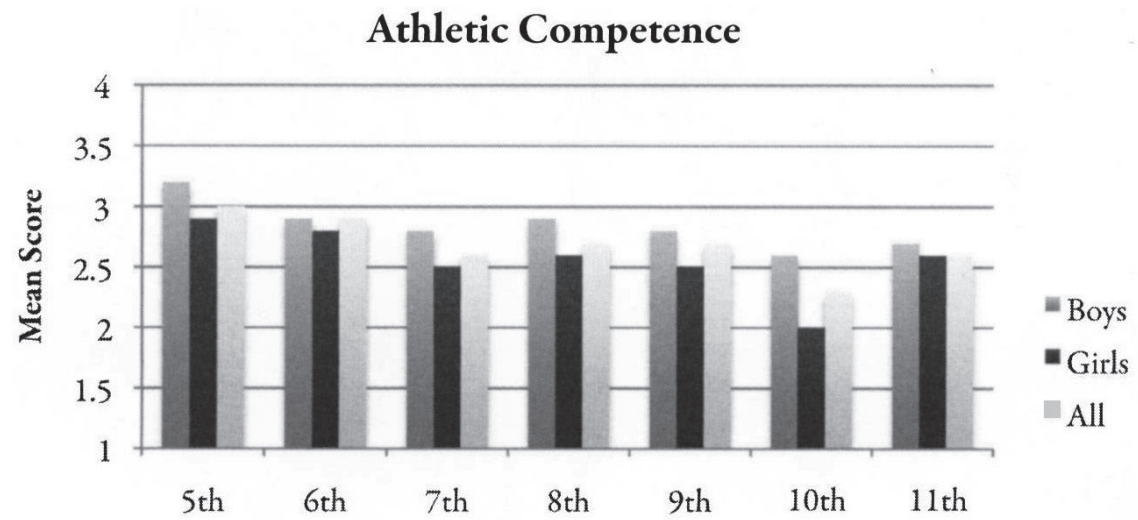

Grade

Figure 3. Mean athletic competence scores for boys, girls, and all students in each grade. 


\section{Physical Appearance}

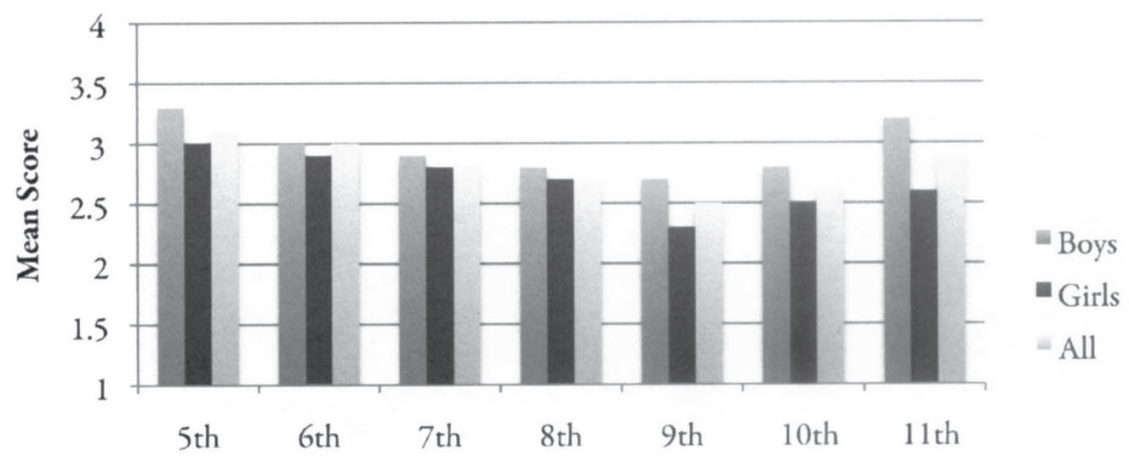

Grade

Figure 4. Mean physical appearance scores for boys, girls, and all students in each grade.

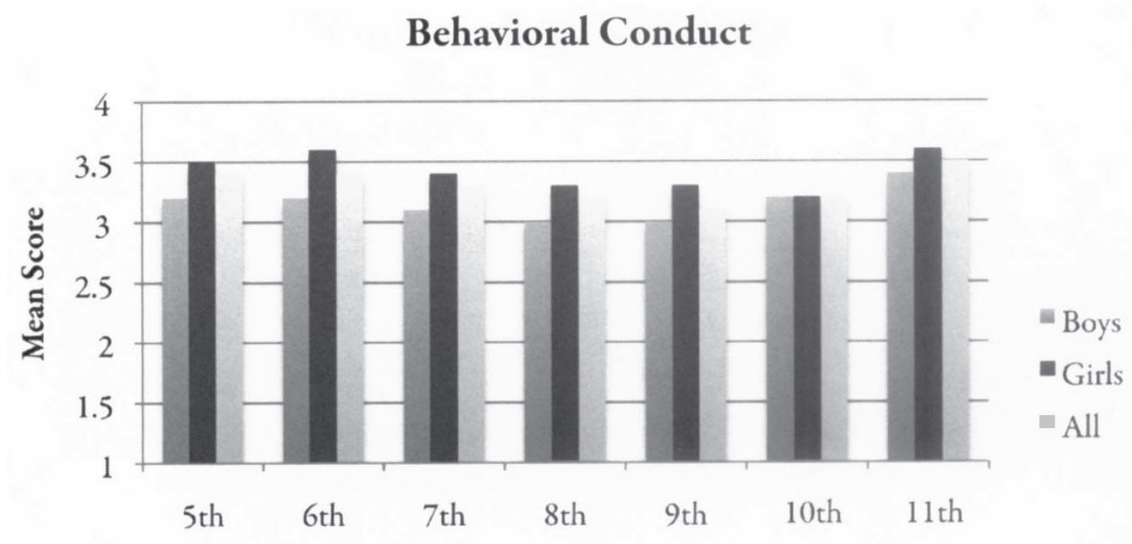

\section{Grade}

Figure 5. Mean behavioral conduct scores for boys, girls, and all students in each grade. 


\section{Global Self-Worth}

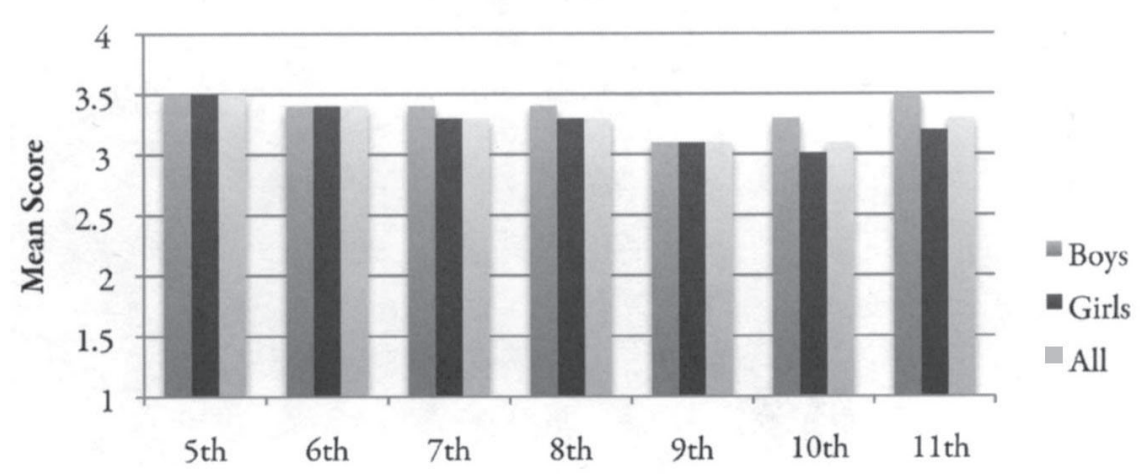

Grade

Figure 6. Mean global self-worth scores for boys, girls, and all students in each grade.

Main Effects for Gender and Grade. Table 4 displays the F ratios resulting from analyses by gender and grade. The two-way MANOVA revealed that boys' and girls' self-concept scores differed significantly, $F(6,491)=11.53, p<.001 .^{1}$ Specifically, boys' average scores were significantly higher than girls' average scores for athletic competence (partial $\left.\eta^{2}=.023\right)$, physical appearance (partial $\eta^{2}=.021$ ), and global self-worth (partial $\eta^{2}=.008$ ). Girls' average scores were significantly higher than boys' scores for behavioral conduct (partial $\eta^{2}=.038$ ). No differences were found between boys' and girls' selfconcept scores in the domains of scholastic competence and social acceptance.

Gifted students' self-concept scores also differed significantly by grade, $F(36,491)=2.66, p<.001$. Pairwise comparisons evaluated with Tukey tests showed that there were two domains in which selfconcept scores were higher for older gifted students: social acceptance (partial $\eta^{2}=.028$ ) and behavioral conduct (partial $\eta^{2}=.034$ ). Specifically, social acceptance scores were significantly higher for grade 8 students than they were for grade 7 students. Behavioral conduct scores were significantly higher for grade 11 students than they were for grade 9 students. Conversely, older students' scores were significantly lower than younger students' scores in the domains of athletic 
Table 4. Posthoc Univariate Analyses of Variance F Ratios for Gender, Grade, and Gender $\times$ Grade for Self-Perception Profile Subscales

\begin{tabular}{lcccccc}
\hline Variable & SC & SA & AC & PA & BC & GSW \\
& F & F & F & F & F & F \\
\hline $\begin{array}{c}\text { Gender }(\mathrm{Ge}) \\
\quad(d f=1,491)\end{array}$ & .01 & .45 & $12.55^{* * *}$ & $11.22^{* * *}$ & $20.56^{* * *}$ & $4.05^{*}$ \\
$\begin{array}{c}\text { Grade }(\mathrm{Gr}) \\
\quad(d f=6,491)\end{array}$ & .90 & $2.40^{*}$ & $3.43^{* *}$ & $4.22^{* * *}$ & $3.09^{* *}$ & $3.27^{* *}$ \\
$\begin{array}{c}\text { Ge } \times \text { Gr } \\
(d f=6,491)\end{array}$ & .78 & 1.00 & .68 & .80 & .40 & .71 \\
\hline
\end{tabular}

Multivariate $F$ ratios were generated from Pillai's Trace statistic. SC $=$ Scholastic Competence, $\mathrm{SA}=$ Social Acceptance, $\mathrm{AC}=$ Athletic Competence, $\mathrm{PA}=$ Physical Appearance, $\mathrm{BC}=$ Behavioral Conduct, GSW $=$ Global Self-Worth. ${ }^{*} p<.05 ;{ }^{* *} p$ $<.01 ;{ }^{* * *} p<.001$

competence (partial $\left.\eta^{2}=.039\right)$, physical appearance (partial $\left.\eta^{2}=.048\right)$, and global self-worth (partial $\eta^{2}=.038$ ). Scores in athletic competence were significantly lower for 10th graders than they were for 5 th and 6th graders. Physical appearance scores were significantly lower for 8th, 9th, and 10th graders than they were for 5th graders and significantly lower for 9 th graders than 6th graders. Finally, the global selfworth scores of 5th graders were higher than those of 9th graders, and scores of 6th graders were higher than those of both 9th and 10th graders. However, by 11th grade, differences between grades were no longer significant. Table 2 contains the means and standard deviations for scores on each subscale by gender and by grade and indicates the statistically significant score differences between grades.

Interaction Between Gender and Grade. There were no statistically significant interactions between gender and grade for scores on any of the self-concept subscales, $F(36,491)=.78, p=.90$.

\section{Grade Differences by Gender for Students Grades 5 to 11}

In order to further examine gender differences in self-concept scores, we conducted multivariate analyses of variance (MANO- 
Table 5. Posthoc Univariate Analyses of Variance F Ratios for Grade for Self-Perception Profile Subscales for Boys and Girls

\begin{tabular}{|c|c|c|c|c|c|c|}
\hline \multirow{3}{*}{$\begin{array}{l}\text { Boys } \\
\text { Variable }\end{array}$} & \multicolumn{6}{|c|}{ Univariate } \\
\hline & SC & SA & $\mathrm{AC}$ & PA & $\mathrm{BC}$ & GSW \\
\hline & $\mathrm{F}$ & $\mathrm{F}$ & F & $\mathrm{F}$ & $\mathrm{F}$ & $\mathrm{F}$ \\
\hline $\begin{array}{l}\text { Grade (Gr) } \\
(d f=6,190)\end{array}$ & .19 & 1.04 & .75 & 2.00 & 1.06 & 1.08 \\
\hline \multicolumn{3}{|l|}{ Girls } & \multicolumn{4}{|c|}{ Univariate } \\
\hline \multirow[t]{2}{*}{ Variable } & SC & SA & $\mathrm{AC}$ & PA & BC & GSW \\
\hline & $\mathrm{F}$ & $\mathrm{F}$ & $\mathrm{F}$ & $\mathrm{F}$ & $\mathrm{F}$ & $\mathrm{F}$ \\
\hline $\begin{array}{l}\text { Grade (Gr) } \\
(d f=6,301)\end{array}$ & 1.78 & $2.58^{*}$ & $3.85^{* * *}$ & $3.24^{* *}$ & $2.80^{*}$ & $3.26^{* *}$ \\
\hline
\end{tabular}

Multivariate $F$ ratios were generated from Pillai's Trace statistic. SC $=$ Scholastic Competence, $\mathrm{SA}=$ Social Acceptance, $\mathrm{AC}=$ Athletic Competence, $\mathrm{PA}=$ Physical Appearance, $\mathrm{BC}=$ Behavioral Conduct, GSW $=$ Global Self-Worth, ${ }^{*} p<.05$; ${ }^{* *} p<$ $.01 ;{ }^{* * *} p<.001$

VAs) separately for boys and girls. There were no statistically significant differences in boys' self-concept scores between grades 5 to $11, F(6,190)=.93, p=.59$. However, girls showed statistically significant differences between grades 5 to 11 in five areas of self-concept, $F(6,301)=2.71, p<.001 .^{2}$ Table 5 shows $F$ ratios for grade separately for boys and girls, and Table 2 displays the corresponding means and standard deviations, as well as statistically significant score differences between grades separately for each gender.

Analyses revealed statistically significant grade differences in girls' self-concept scores for social acceptance (partial $\left.\eta^{2}=.049\right)$, athletic competence (partial $\eta^{2}=.071$ ), physical appearance (partial $\eta^{2}$ $=.061$ ), behavioral conduct (partial $\eta^{2}=.053$ ), and global self-worth (partial $\eta^{2}=.061$ ). These effect sizes are a bit larger than those resulting from examinations of self-concept scores across the whole sample and, again, suggest practical significance for these findings. 
Posthoc univariate $F$ tests followed by pairwise comparisons using Tukey tests indicated that self-concept scores were lower among older girls in athletic competence, physical appearance, and global self-worth (see Table 2). Specifically, scores for perceptions of athletic competence were significantly lower for girls in 10th grade than they were for girls in 5th, 6th, and 8th grades. For physical appearance, self-concept scores were significantly lower for girls in ninth grade than they were for girls in 5th and 6th grades. Global self-worth scores were significantly lower for girls in 9th and 10th grades than they were for girls in 6th grade. For social acceptance and behavioral conduct, no specific grade differences were detected. However, when younger girls' scores (grades 5 to 7 ) were compared to adolescent girls' scores (grades 8 to 11), a significant difference emerged for behavioral conduct but not for social acceptance. Specifically, behavioral conduct scores were lower among preadolescents (grades 5 to 7 ) than adolescents (grades 8 to 11).

\section{Discussion}

In general, mean self-concept scores for the current sample were higher than those found with heterogeneous samples of same-aged students (Harter, 1985, 1988), suggesting that gifted students' selfconcepts are more positive than those of nonidentified students. Indeed, it appears that giftedness or high academic ability may be a protective factor for students' self-concept, buffering students from the biggest dips in self-concept typically experienced in adolescence.

\section{Grade Differences Among Students from 5th to 11th Grade}

A comparison of the participants on the six commonly administered Harter subscales (i.e., scholastic competence, social acceptance, athletic competence, physical appearance, behavioral conduct, and global self-worth) revealed significant differences between some of the older and younger groups. An investigation of the student sample along the age continuum uncovered a significant difference in mean scores on athletic competence and global self-worth, with an overall decline through 10th grade but a slight rebound for students in 11th 
grade. Similar results were found by Jacobs, Lanza, Osgood, Eccles, and Wigfield (2002), whose female sample experienced a slight increase in their language arts self-concept at the end of high school. Further investigation is necessary to determine why a resurgence of self-concept occurs at the end of high school for some adolescents. Differences in mean scores between some groups on physical appearance scores were consistent with Cornell et al.'s (1990) study with a similar sample. The only scale on which significant differences indicated higher scores for older students was behavioral conduct (higher scores for 11th graders than 9th graders). Contrary to the general downward trend of students' athletic competence, physical appearance, and global self-worth scores, social acceptance scores increased which could reflect these students' relative familiarity with their school system and social networks. However, there remains a lack of research documenting similar conclusions. Even though the general trends were in the directions indicated, there was variation from grade to grade within that trend, and self-concept scores for this sample were typically above the average in all domains.

Although scores in most domains varied between grades, no significant differences emerged between grades on the scholastic competence subscale. Rudasill and Callahan's (2008) findings regarding the psychometric properties of the SPPC and SPPA using the same sample illuminated a possible explanation for this finding. They confirmed the validity and reliability of all subscales of Harter's Self-Perception Profiles (SPPC and SPPA) for use with gifted populations. The exception was scholastic competence, which had lower reliability than Harter $(1985,1988)$ reported. The lower reliability of the scholastic competence subscale is perhaps due to the nature of this sample's attenuated range; the more the range is restricted, the more difficult it is to achieve reliability. The low reliability also is conceivably inherent in a sample of students who excel in academics. Consequently, among the gifted student population, the scholastic competence subscale is the least reliable of Harter's Self-Perception Profile subscales and does not follow the same patterns and trends as the other subscales. On a positive note, this restriction of range occurred at the high end of the scale, indicating that students in this study felt academically competent. 


\section{Gender Differences among Students from 5th to 11th Grade}

In addition to the significant differences found between grades, significant gender differences emerged. Consistent with previous research (Cornell et al., 1990; Schneider, Clegg, Bryne, Ledingham, \& Crombie, 1989) and congruent with current gender stereotypes, girls had significantly higher behavioral conduct scores than boys. Also consistent with the literature (Cornell et al., 1990), boys had significantly higher physical appearance, global self-worth, and athletic competence scores. Jacobs' et al. (2002) findings suggest that both boys and girls experience a drop in their self-concept in all academic abilities as they age, but, when comparing the current student sample across the age continuum, the male profile contrasted with the female profile. Although boys' physical appearance selfconcept scores showed a nonsignificant negative trend as grade increased, boys showed no significant changes in self-concept across grades. Conversely, the girls' scores revealed statistically significant differences, suggesting a decline in almost every domain of self-concept as grade increased. The exceptions were scholastic competence, which seemed to be affected by restricted range, and social acceptance. Of most concern is the decline in global self-worth. The current findings, in conjunction with the existing literature (Bell, 1989; Colangelo \& Assouline, 1995; Kline \& Short, 1991; Kline \& Zehms, 1996; Reis, 1987, 1998, 2002; Silverman, 1995), suggest a disconcerting trend: As females advance through school, their self-concept declines.

Although the overall self-concept scores of the sample indicate positive self-reflection on the part of gifted students and the scholastic competence scores remained high across grades, the finding that older girls' self-concept scores were lower than those of younger girls is disheartening. The attempts to create environments where females come to see themselves as positive actors in their own lives and to evaluate themselves positively seem to be limited in some respects. However, it is important to acknowledge that girls' self-concept scores fluctuated from grade to grade and seemed to rebound in 11th grade when students are beginning to make important college and career decisions. 


\section{Limitations}

Three limitations to this study require mention. The first is a question of external validity. Ideally, students' self-concepts would be assessed in their typical environments (i.e., school). On the one hand, while students were carefully instructed to reflect on their home schools and peers when completing the questionnaire, they may have been influenced by the BFLPE in the two days of experience at the summer program. The high scores on academic self-concept suggest that this effect is minimal because we would have expected to see the greatest effect on those scores. Nonetheless, this limitation should be noted. On the other hand, simply being accepted into and attending a summer program for gifted students and being among other highly able students may have inflated their sense of accomplishment and academic self-concept.

In addition, the lack of information regarding each participant's home school grade structure (e.g., K-5, 6-8, and 9-12 vs. K-6, 7-8, and 9-12) and gifted program type (e.g., school for the gifted, pullout program, gifted classes) limits interpretation of the findings. Understanding each participant s school grade structure would have clarified our conclusions. Other studies (Wigfield, Eccles, Iver, Reuman, \& Midgley, 1991 ) have suggested school transition directly affects self-concept. Transitions from elementary to middle school (typically fifth to sixth grade) and again from middle to high school (typically eighth to ninth grade) are more challenging for students than transitions between other grades because students move from being the oldest to being the youngest while simultaneously adjusting to a new academic and social environment. Therefore, without knowing when students are transitioning between schools, our ability to understand the reasons behind the particular grade differences in self-concept profiles was somewhat limited. There also is evidence that gifted program type is related to self-concept. Specifically, elementary students in separate classes for the gifted had lower self-concepts than gifted students in other types of programs (e.g., within-class programs, pull-out programs) and nonidentified students (Delcourt, Cornell, \& Goldberg, 2007). Information about the gifted programs (if any) in which the students participated in 
their home schools would have deepened our understanding of selfconcept with this sample.

Finally, the sample was a convenience sample, comprised primarily of Caucasian middle-class students. Thus, we cannot make any generalizations to other populations of gifted students.

\section{Future Research}

Our findings point to areas of future study. These include research within the school setting. Rather than having students refer to their home schools in responding to the questions, having students complete the instrument during the school year and within their home schools and classrooms would provide a better assessment of their self-concepts in the context in which these students interact daily. Additionally, a longitudinal study that follows the same sample across several years-rather than a cross-sectional study - could provide information about change for particular individuals. A within-school study, or a replication of the current study, also could involve corroborating qualitative data, including information gleaned from observations of and interviews with participants. In addition, future research should focus on the self-concepts of different populations of gifted students, such as African American and Hispanic students, and students from lower socioeconomic backgrounds.

These research suggestions and call for replication are an attempt to better understand the reliability of and reasons for the moderate self-concept rebound in 11th grade and the overall decline in the selfconcept of gifted females, a disturbing and detrimental trend not only for the gifted students directly affected but for our society as a whole.

\section{References}

Bandura, A. (1997). Self-efficacy: The exercise of control. New York: W. H. Freeman.

Bell, L. (1989). Something's wrong here and it's not me: Challenging the dilemmas that block girls' success. Journal for the Education of the Gifted, 12, 118-130. 
Byrne, B. M. (1984). The general/academic self-concept nomological network: A review of construct validation research. Review of Educational Research, 54, 427-456.

Byrne, B. M., \& Shavelson, R.J. (1986). On the structure of adolescent selfconcept. Journal of Educational Psychology, 78, 474-481.

Chan, D. W. (2001). Global and specific self-concepts of gifted adolescents in Hong Kong. Journal for the Education of the Gifted, 24, 344-364.

Colangelo, N., \& Assouline, S. G. (1995). Self-concept of gifted students: Patterns by self-concept domain, grade level, and gender. In M. W. Katzko \& F. J. Mönks (Eds.), Nurturing talent: Individual needs and social ability (pp. 66-74). Assen, The Netherlands: Van Gorcum.

Cornell, D. G., Delcourt, M. A. B., Goldberg, M. D., \& Bland, L. C. (1995). Achievement and self-concept of minority students in elementary school gifted programs. Journal for the Education of the Gifted, 18, 189-209.

Cornell, D., Pelton, G., Basin, L., Landrum, M., Ramsay, S., Cooley, M., et al. (1990). Self-concept and peer status among gifted program youth. Journal of Educational Psychology, 82, 456-463.

De Fraine, B., Van Damme, J., \& Onghena, R (2007). A longitudinal analysis of gender differences in academic self-concept and language achievement: A multivariate multilevel latent growth approach. Contemporary Educational Psychology, 32, 132-150.

Delcourt, M. A. B., Cornell, D. G., \& Goldberg, M. D. (2007). Cognitive and affective learning outcomes of gifted elementary school students. Gifted Child Quarterly, 51, 359-381.

Dixon, F. A., Cross, T. L., \& Adams, C. M. (2001). Psychological characteristics of academically gifted students in a residential setting: A cluster analysis. Psychology in the Schools, 38, 433-445.

Hamachek, D. (1995). Self-concept and school achievement: Interaction dynamics and a tool for assessing the self-concept component. Journal of Counseling \& Development, 73, 419-425.

Hansford, B. C, \& Hattie, J. A. (1982). The relationship between self and achievement/performance measures. Review of Educational Research, 52, 123-142.

Harter, S. (1985). Manual for the Self-Perception Profile for Children. Denver, CO: University of Denver.

Harter, S. (1988). Manual for the Self-Perception Profile for Adolescents. Denver, CO: University of Denver. 
Harter, S. (2006). The self. In W. Damon \& N. Eisenberg (Eds.), Handbook of child psychology: Vol 3. Social, emotional, and personality development (6th ed., pp. 505-570). New York: Wiley.

Hoge, R., \& McSheffrey, R. (1991). An investigation of self-concept in gifted children. Exceptional Children, 57, 238-245.

Jacobs, J. E., Lanza, S., Osgood, D. W., Eccles, J. S., \& Wigfield, A. (2002). Changes in children's self-competence and values: Gender and domain differences across grades one through twelve. Child Development, 73, 509-527.

Kline, B., \& Short, E. (1991). Changes in emotional resilience: Gifted adolescent females. Roeper Review, 13, 118-121.

Kline, A. G., \& Zehms, D. (1996). Self-concept and gifted girls: A crosssectional study of intellectually gifted females in grades $3,5,8$. Roeper Review, 19, 30-34.

Kling, K. C, Hyde, J. S., Showers, C. J., \& Buswell, B. N. (1999). Gender differences in self-esteem: A meta-analysis. Psychological Bulletin, $125,470-500$.

Li, A. K. F. (1988). Self perception and motivational orientation in gifted children. Roeper Review, 10, 175-180.

Marsh, H. W. (1986). Verbal and math self-concepts: An internal/external frame of reference model. American Educational Research Journal, 23, 129-149.

Marsh, H. W. (1987). The big-fish-little-pond effect on academic self-concept. Journal of Educational Psychology, 79, 280-295.

Marsh, H. W (1990). The structure of the academic self-concept: The Marsh/Shavelson model. Journal of Education Psychology, 82, 623-636.

Marsh, H. (1992). Self-Description Questionnaire III. New South Wales, Australia: University of Western Sydney.

Marsh, H. W, \& Craven, R. G. (2006). Reciprocal effects of self-concept and performance from a multidimensional perspective: Beyond seductive pleasure and unidimensional perspectives. Perspectives on Psychological Science, 1, 133-163.

Marsh, H. W, Craven, R. G., \& Debus, R. (1991). Self-concepts of young children 5 to 8 years of age: Measurement and multidimensional structure. Journal of Educational Psychology, 83, 377-392.

Marsh, H. W, \& Parker, J. W (1984). Determinants of student self-concept: Is it better to be a relatively large fish in a small pond even if you 
don't learn to swim as well? Journal of Personality and Social Psychology, 47, 213-231.

Muldoon, O., \& Reilly, J. (2003). Career choice in nursing students: Gendered constructs as psychological barriers. Journal of Advanced Nursing, 43, 93-100.

Olszewski-Kubilius, P., \& Turner, D. (2002). Gender differences among elementary school-aged gifted students in achievement, perceptions of ability, and subject preference. Journal for the Education of the Gifted, 25, 233-268.

Osipow, S. (1983). Theories of career development. Englewood Cliffs, NJ: Prentice-Hall.

Pajares, E., \& Schunk, D. (2001). Self-beliefs and school success: Self-efficacy, self-concept, and school achievement. In R. Riding \& S. Rayner (Eds.), Perception (pp. 239-266). London: Ablex.

Plucker, J., \& Stocking, V. (2001). Looking outside and inside: Self-concept development of gifted adolescents. Exceptional Children, 67, 535-548.

Reis, S. M. (1987). We can't change what we don't recognize: Understanding the special needs of gifted females. Gifted Child Quarterly, 31, 83-89.

Reis, S. M. (1998). Work left undone: Choices and compromises of talented females. Mansfield Center, CT: Creative Learning Press.

Reis, S. M. (2002). Gifted females in elementary and secondary school. In M. Neihart, S. M. Reis, N. M. Robinson, \& S. M. Moon (Eds.), The social and emotional development of gifted children: What do we know? (pp. 13-18). Waco, TX: Prufrock Press.

Rudasill, K. M., \& Callahan, C. M. (2008). Psychometric characteristics of the Harter Self-Perception Profiles for Adolescents and Children for use with gifted populations. Gifted Child Quarterly, 52, 72-86.

Schneider, B., Clegg, M., Byrne, B., Ledingham, J., \& Crombie, G. (1989). Social relations of gifted children as a function of age and school program. Journal of Educational Psychology, 81, 48-56.

Shavelson, R. J., \& Bolus, R. (1982). Self-concept: The interplay of theory and methods. Journal of Educational Psychology, 74, 3-17.

Shavelson, R. J., Hubner, J. J., \& Stanton, G. C. (1976). Self-concept: Validation of construct interpretations. Review of Educational Research, $46,407-441$. 
Silverman, L. (1995). To be gifted or feminine: The forced choice of adolescence. Journal of Secondary Gifted Education, 6, 141-156.

Soares, L. M., \& Soares, A. T. (1983, April). Components of students' self related cognitions. Paper presented at the meeting of the American Educational Research, Montreal, Canada. (ERIC Document Reproduction Services No. ED228317)

Strein, W. (1993). Advances in research on academic self-concept: Implications for school psychology. School Psychology Review, 22, 273-284.

Tenenbaum, H., \& Leaper, C. (2003). Parent-child conversations about science: The socialization of gender inequities? Developmental Psychology, 39, 34-47.

VanTassel-Baska, J., Olszewski-Kubilius, P., \& Kulieke, M. (1994). A study of self-concept and social support in advantaged and disadvantaged seventh and eighth grade gifted students. Roeper Review, 16, 186-191.

Wigfield, A., Eccles, J. S., Iver, D. M., Reuman, D. A., \& Midgley, C. (1991). Transitions during early adolescence: Changes in children's domainspecific self-perceptions and general self-esteem across the transition to junior high school. Developmental Psychology, 27, 552-565.

\section{Endnotes}

1. Multivariate $F$ ratios were generated from Pillais Trace statistic. Pillais Trace statistics were .125 for gender, .189 for grade, and .051 for Gender $\times$ Grade.

2. Multivariate $F$ ratios were generated from Pillai's Trace statistic. Pillais Trace statistics were .171 for boys and .308 for girls. 